\title{
Ellipsis
}

Volume 44

Article 23

2017

\section{Yo Amor}

Ben Aleshire

University of New Orleans

Follow this and additional works at: https://scholarworks.uno.edu/ellipsis

\section{Recommended Citation}

Aleshire, Ben (2017) "Yo Amor," Ellipsis: Vol. 44 , Article 23.

DOI: https://doi.org/10.46428/ejail.44.23

Available at: https://scholarworks.uno.edu/ellipsis/vol44/iss1/23

This Poetry is brought to you for free and open access by the Department of English and Foreign Languages at ScholarWorks@UNO. It has been accepted for inclusion in Ellipsis by an authorized editor of ScholarWorks@UNO.

For more information, please contact scholarworks@uno.edu. 


y $\quad$ a mor

La palabra 'y' no puede escoger nada ni siquiera entre los dos cuernos que pone y nunca estara satisfecha

La palabra ' $O$ ' es el sonido de satisfacer escapando nuestras gargantas por que siempre escoje uno o otro y asi la palabra 'amor' esta embarazada con la luna llenissima de esa Ietra, con su infinitud de elegir.

- para Francisca

Plaza Nueva, Granada, Spain 